Krzysztof Andruczyk

Wydział Filologiczny

Uniwersytet w Białymstoku

e-mail: andruczyk.krzysztof@gmail.com

\title{
Oblicza Północy w Agaj-Hanie Zygmunta Krasińskiego
}

Tematyka Północy stanowi jedno z najszerszych i najbardziej złożonych zagadnień w historii literatury romantycznej. "Odkryta” na Zachodzie Europy w drugiej połowie XVIII wieku, „literatura Północy” dociera na ziemie polskie na początku dziewiętnastego stulecia wraz z publikacją pierwszego tłumaczenia Eddy (1807) autorstwa Joachima Lelewela. O niezwykle żywej recepcji problematyki Północy u progu polskiego romantyzmu świadczą liczne dzieła literackie noszące ślady inspiracji Edda czy Pieśniami Osjana oraz prace teoretyczne, których autorzy - jak m.in. Maurycy Mochnacki - doszukiwali się często historycznych związków między literaturą polską a twórczością "ludów Północy". Wśród twórców głęboko zainteresowanych romantycznym wizerunkiem Północy znalazł się również Zygmunt Krasiński. Zarówno dzieła literackie, jak i bogata epistolografia autora Nie-Boskiej Komedii świadczą o bardzo głębokim i zindywidualizowanym pojmowaniu tematu Północy. Obszerniejsza refleksja poety na temat geograficznej przynależności Polski oraz jej związków z szeroko rozumianą Północą została zawarta w listach do Henryka Reeve'a pisanych pod koniec 1831 roku. Jest to również czas, w którym Krasiński tworzy Agaj-Hana - powieść, która stała się literackim odzwierciedleniem poglądów poety na temat Północy.

Agaj-Han powstawał na przełomie 1831 i 1832 roku w czasie pobytu Krasińskiego w Genewie. Zbigniew Suszczyński nazwał ten okres biografii poety mianem „miesięcy najgłębszego kryzysu moralnego” ${ }^{1}$. Powieść Krasin-

1 Z. Suszczyński, „Agaj-Han”, czyli romantyczna frenezja Zygmunta Krasińskiego, w: Z. Krasiński, Agaj-Han, Białystok 1998, s. 10. 
skiego rodziła się w cieniu osobistej tragedii, jaką było podporządkowanie się rozkazowi ojca-lojalisty zabraniającego jedynakowi udziału w powstaniu listopadowym. Traumatyczne przeżycia poety przeniknęły również na karty powieści, której akcja rozgrywa się w siedemnastowiecznej Rosji epoki Dymitriad. W powieści Krasińskiego ścierają się ze sobą dwa wizerunki Rosji przedstawianej z jednej strony jako niezwykle barwny, choć chylący się ku upadkowi świat Wschodu ${ }^{2}$, z drugiej: jako skute wiecznym lodem, złowrogie państwo Północy ${ }^{3}$.

Bohaterami Agaj-Hana Krasiński uczynił jednostki poddane destruktywnym namiętnościom, dążące - podobnie jak otaczający je świat historii do samozagłady. Wydarzenia opisane $\mathrm{w}$ powieści są poetyckim przełożeniem Dziejów Panowania Zygmunta III Juliana Ursyna Niemcewicza - trzytomowego, monumentalnego dzieła historycznego, które stało się ulubioną lekturą Krasińskiego w czasach jego pobytu w Genewie ${ }^{4}$. Historia Maryny, Zaruckiego i tytułowego Agaj-Hana zostały przez autora zamknięte w ramach zrytmizowanej prozy poetyckiej. Niezwykle oryginalna forma utworu stała się przyczyną wątpliwości badaczy twórczości Krasińskiego co do artystycznej rangi i miejsca Agaj-Hana w twórczym dorobku poety.

2 Na temat wschodniej proweniencji świata przedstawionego w Agaj-Hanie powstało wiele, dziś już klasycznych studiów literaturoznawczych. Juliusz Kleiner wyróżnił orientalne elementy powieści, zaś za modelowego przedstawiciela Orientu uznał tytułowego bohatera, którego określił mianem „mozaiki różnorodnych sfer Wschodu”. O ojczyźnie Agaj-Hana, o której opowiada sam bohater powieści, Kleiner pisał: „Wschodu, który zawarty jest w tym żyjącym muzeum świetności i grozy [tj. w ojczyźnie bohatera - dop. K.A.], niepodobna zlokalizować na mapie geograficznej; za to nietrudno go znaleźć na mapie literatury; od powieści Tysiąca i jednej nocy do Moore'a i Byrona [...] (zob. J. Kleiner, Zygmunt Krasiński. Studia, Warszawa 1998, s. 120). Romantyczna fascynacja Orientem uwidocznia się również w słownictwie tytułowego bohatera (zob. klasyczne studium Marii Janion, "Agaj-Han" jako romantyczna powieść historyczna w: tejże, Romantyzm. Studia o ideałach i stylu, Warszawa 1969, s. 53-59). Mianem Wschodu w powieści bywa określana również Rosja. Odmienność Wschodniego Imperium wobec świata Zachodu zostaje podkreślona w wielu partiach narracyjnych powieści, m.in. „Nowy to świat był Polakom, wschodni, szeroki, otwarty na stratowanie końskimi podkowy" (Z. Krasiński, Agaj-Han, Białystok 1998, s. 94). Na temat wizerunku Rosji w Agaj-Hanie zob. J. Fiećko, Rosja Krasińskiego. Rzecz o nieprzejednaniu, Poznań 2005, s. 197-220.

3 Na temat krajobrazu Północy w Agaj-Hanie Krasińskiego pisał ostatnio Tomasz Łuczkowski w interesującym szkicu Pejzaż Pótnocy w "Agaj-Hanie” Krasińskiego (Pótnoc - Od wzniosłości do konwulsji), w: Zygmunt Krasiński - nowe spojrzenia, red. G. Halkiewicz-Sojak, B. Burdziej, Torun 2001, s. 166-185.

4 Z. Suszczyński, "Agaj-Han” jako romantyczna frenezja Zygmunta Krasińskiego, s. 12. Szczegółowo o inspiracji Krasińskiego dziełem Niemcewicza pisała Elżbieta Dąbrowicz w artykule: "Agaj-Han" jako świadectwo lektury "Dziejów panowania Zygmunta III" Juliana Ursyna Niemcewicza, w: Zygmunt Krasiński. Światy poetyckie i artystowskie, red. A. Markuszewska, Toruń 2014, s. 61-82. W swoim tekście badaczka w bardzo interesujący sposób pisze o Agaj-Hanie jako swoistym „sprawozdaniu” z upadku Królestwa Kongresowego. 
Stanisław Tarnowski zwrócił szczególną uwagę na "chwiejność stylu” Agaj-Hana, który w niektórych partiach przywodzi na myśl najdoskonalsze dzieła poety, w innych zaś przedstawia się jako utwór niedojrzały ${ }^{5}$. Istotę poglądów Tarnowskiego trafnie charakteryzuje Elżbieta Dąbrowicz: „Ekwilibrystyka, którą Tarnowski ryzykuje w swoim wywodzie, jest odpowiedzią na wewnętrznie sprzeczną naturę omawianego dzieła, chwilami poruszająco autentycznego, częściej jednak nieznośnie sztucznego, minoderyjnego, a w końcu i pretensjonalnego" 6 .

Nieco przychylniej o Agaj-Hanie wypowiadał się Juliusz Kleiner. Badacz uznał wprawdzie Agaj-Hana za dzieło mało samodzielne, zależne od poetyki "pseudoromantycznej" 7 , jednak w prozie poetyckiej utworu dostrzegł mimo to zwiastunkę prozatorskich ustępów z najwybitniejszych dramatów Krasińskiego, a także „zapowiedź napięć tragicznych i zwartego ujmowania wielkich dziejów i ludzi w utworach późniejszych"8.

Nobilitacji powieści dokonała Maria Janion, uznając Agaj-Hana za przejaw „romantycznego ekspresjonizmu” - nurtu prekursorskiego wobec jego odmiany dwudziestowiecznej. W niecodziennym stylu Agaj-Hana badaczka dostrzegła w pełni świadomy zabieg artystyczny dziewiętnastoletniego Krasińskiego, który podczas swojego pobytu w Genewie poszukiwał usilnie indywidualnego wyrazu poetyckiego. Agaj-Han miałby więc być zwieńczeniem genewskiej twórczości Krasińskiego, jak również symbolicznym podsumowaniem młodzieńczego okresu twórczości. W odróżnieniu od Tarnowskiego i Kleinera, Janion dostrzegła również wyraźny związek między „ekspresjonistyczną" prozą poetycką Agaj-Hana a historiozoficzną ideą Krasińskiego. Maria Janion uznaje zatem Agaj-Hana z jednej strony za dzieło domykające genewski okres twórczości, z drugiej za zwiastun najwybitniejszych dokonań poety ${ }^{9}$.

Za dzieło „utraconej szansy” uważa Agaj-Hana Jerzy Fiećko. Zdaniem badacza Krasiński nie wykorzystał w pełni możliwości podjętego tematu historycznego związanego z przedstawioną w powieści epoką Dymitriad. Poza tym autor Agaj-Hana miał powtórzyć w swojej powieści negatywne stereotypy dotyczące Rosji, które można odnaleźć we wczesnych fragmentach prozator-

5 S. Tarnowski, Studia do historii literatury polskiej: wiek XIX. Zygmunt Krasiński, Kraków 1893, s. 52.

6 E. Dąbrowicz, "Agaj-Han” jako świadectwo „Dziejów panowania Zygmunta III" Juliana Ursyna Niemcewicza, s. 62.

7 J. Kleiner, Zygmunt Krasiński. Studia, s. 120.

8 Tamże, s. 127.

9 M. Janion, „Agaj-Han” jako romantyczna powieść historyczna, s. 49-79. 
skich poety, co tym samym zbliża Agaj-Hana do problematyki twórczości młodzieńczej ${ }^{10}$.

Przytoczone opinie nie pozwalają na jednoznaczne wskazanie miejsca Agaj-Hana w dorobku Krasińskiego. Zbierając powyższe sądy, można uznać, że genewska powieść jawi się jako dzieło znajdujące się niejako "pośrodku” twórczej drogi Krasińskiego: utwór miałby stanowić albo późny produkt twórczości młodzieńczej (Tarnowski, Fiećko) albo dzieło zapowiadające późniejsze dokonania $\mathrm{w}$ dziedzinie dramatu (Kleiner) czy też miałby być dziełem zupełnie odrębnym od całej dotychczasowej twórczości, świadomym, obszernym eksperymentem literackim podsumowującym okres genewskich poszukiwań w dziedzinie prozy poetyckiej (Janion).

Uznanie Agaj-Hana za dzieło graniczne wydaje się być najwłaściwszym rozwiązaniem problemu miejsca powieści w dorobku poety. Agaj-Han łączy pierwsze doświadczenia pisarskie Krasińskiego (frenezję, gotycyzm), eksperymenty stylowe uwidocznione $\mathrm{w}$ genewskich fragmentach prozą, $\mathrm{z}$ dojrzałą wizją historiozoficzną, która tym samym pozwala uznać go za utwór zapowiadający problematykę Irydiona i Nie-Boskiej Komedii. Genewska powieść jest zarazem pierwszym utworem Krasińskiego syntetyzującym indywidualne rozumienie Północy, z którym poeta zetknął się jeszcze w okresie młodzieńczej twórczości. Interpretacja „północnej” problematyki Agaj-Hana, będącej głównym tematem niniejszego szkicu, winna zostać - w mojej opinii poprzedzona próbą rekonstrukcji poglądów Krasińskiego na temat recepcji szeroko rozumianej Północy w dobie romantyzmu.

\section{Północ w refleksji Krasińskiego}

W swojej rozprawie poświęconej polskiej „poezji Północy” Hieronim Chojnacki nazywa Krasińskiego mianem "przekonanego przeciwnika Północy"11. Swój - radykalny bądź co bądź - osąd badacz opiera na listach poety adresowanych do Delfiny Potockiej, w których Krasiński zdradza własne zamiłowanie do krajów Południa ${ }^{12}$. W dalszych partiach pracy badacz omawia wątki północne w Irydionie, a więc w zupełnie już dojrzałym dziele

10 J. Fiećko, Rosja Krasińskiego. Rzecz o nieprzejednaniu, s. 218-220.

11 H. Chojnacki, Polska „poezja Pótnocy”. "Maria” - „Irydion” i „Lilla Weneda”, Gdańsk 1998, s. 28. O stosunku Krasińskiego do Północy Chojnacki pisze w następujących słowach: „Nader często $\mathrm{w}$ listach pisanych z krain zaalpejskich dawał (Krasiński - przyp. K.A.) wyraz swej niechęci do owej domeny, która już w swym wymiarze przyrodniczo-klimatycznym była dlań obca, bo ponura, pozbawiona światła, wręcz trupia" (s. 100).

12 Tamże, s. 100. 
Krasińskiego, wskazując na negatywne konotacje Północy, która w dramacie utożsamiona zostaje z Rosją. Opinia Chojnackiego wymaga w moim odczuciu pewnego uściślenia. W swoich studiach nie bierze on pod uwagę młodzieńczego zafascynowania poety literaturą Północy, o której po latach napisze w liście do Franciszka Morawskiego: „Ja nieraz płaczę za średnimi wiekami, za ową poezją, która utworzyła Danta i dźwignęła katedry gotyckie. Jako błyskawicy służą za tło czarne chmury, tak jej tłem były podania Północy, skandynawskie sagi [...]".

W jednym z genewskich listów do Henry'ego Reeve'a Krasiński dokonuje swoistej konfrontacji metaforyki Północy i Południa:

brzęczenie pszczoły, piosenka strumienia wśród kamyków nie są bynajmniej godnym akompaniamentem miłości. Miłości trzeba chmury, co pełna majestatu płynie powoli po lazurze, góry ogromnej, nieruchomej, gromu huczącego głosem Pana, błyskawicy rozświetlającej horyzont, wściekłej fali wznoszącej się z otchłani mórz; wszystko, co wielkie, straszliwe, wzniosłe, olbrzymie sprawi ulgę namiętnemu sercu $[\ldots]^{13}$.

Wypowiedzi Krasińskiego, choć niewolne od romantycznej egzaltacji, stanowią wyraz szczególnej fascynacji poety romantycznym, północnym pejzażem. Poza typowym dla epoki przeżywaniem wzniosłej natury, przedpowstaniowe listy Krasińskiego nie przynoszą jednak spójnej refleksji na temat romantycznego postrzegania Północy - krystalizuje się ona prawdopodobnie już po wybuchu powstania, co wyraźnie uwidocznia się w liście do Reeve'a $\mathrm{z}$ listopada 1831. Krasiński podejmuje $\mathrm{w}$ nim ostrą polemikę z poglądami Joachima Lelewela - jednego z pierwszych popularyzatorów „literatury Północy" na ziemiach polskich:

Bo my ujrzymy, jak świat zachodni coraz głębiej będzie zapadał się w otchłań, ale może nie zdążymy oglądać, jak polski, północny świat odzyska życie i siły. (...) Lelewel to łotr, chciał skazić czystość, żywą wiarę i wzniosłość Północy przywarami i obłędami Zachodu, a wszyscy przebywający obecnie w Paryżu Polacy to ludzie interesowani albo otumanieni, albo półgłówki ${ }^{14}$.

Powyższe słowa stanowią element dłuższego wywodu poety, który zepsutemu moralnie Zachodowi przeciwstawia Północ - wzniosłą i nieskażoną przywarami Okcydentu krainę, do której - za Mochnackim - chciałby zaliczyć również Polskę. Podobne rozumienie Północy Krasiński zaczerpnął z lektury romantycznych poetów niemieckich (Herdera, Richtera, Novalisa),

13 Z. Krasiński, Listy do Henryka Reeve, t. 1, przeł. A. Olędzka-Frybesowa, oprac. P. Hertz, Warszawa 1980, s. 49.

14 Tamże, s. 609 [podkr. - K.A.]. 
zasłynęli oni jako fundatorzy romantycznego mitu Północy w literaturze niemieckiej ${ }^{15}$. Dalszą część swojego wywodu Krasiński utrzymuje w charakterystycznym tonie romantycznego mesjanizmu, niespotykanym $\mathrm{w}$ jego wcześniejszych pismach:

My, ośmielam się rzucić te słowa w twarz całej Europie, i oszalałej Francji, i dumnej Anglii, my, choć uciskani, okuci w kajdany, więcej mamy sił żywotnych niż Francja i niż Anglia, bo nasze ogromne lasy mogą jeszcze dać schronienie duchom, podaniom i zjawom, bo my jeszcze mocno wierzymy w prawdę Bożą i niewiele brakuje, abym uwierzył, że jesteśmy narodem wybranym czasów nowożytnych, że gdy w całej Europie nie będzie już nic poza gruzami i milczeniem, od nas wyjdzie odrodzenie; że ponad grobowce Zachodu i Południa z nas wytryśnie nowe, potężne życie ${ }^{16}$.

Niechęć, z jaką dziewiętnastoletni Krasiński pisał o Lelewelu, wynikała z zupełnie odmiennych stanowisk obu pisarzy wobec problemu romantycznej Północy. Cytowane wypowiedzi Krasińskiego świadczą o dość bezkrytycznym zaaprobowaniu rozumowania Maurycego Mochnackiego, który w rozprawie $O$ duchu i źródłach poezji w Polszcze za kolebkę literatury polskiej uznaje "pieśni skaldów” oraz mitologię nordycką ${ }^{17}$. Rozumowanie Mochnackiego, wiedzionego fascynacją pismami Czackiego i wczesnego Lelewela, musiało również wynikać z chęci umiejscowienia ojczystej literatury w konkretnej tradycji mitologicznej, której - jak wiadomo - Polska nie posiadała. Krasiński staje się z kolei entuzjastą postrzegania Polski jako ostatniego na kontynencie miejsca, które zachowało pierwotność natury przynależną w jego mniemaniu historycznej Północy. Autor Agaj-Hana uznaje tym samym ojczyznę za przestrzeń nieskażoną przez zepsutą - w jego mniemaniu - cywilizacje Zachodu, która w dalekiej przyszłości ma zostać uzdrowiona przez żywioł płynący z Polski.

Ekscytacji Krasińskiego nad pierwotnością i wzniosłością Północy nie podzielał Joachim Lelewel - początkowo popularyzator literatury skandynawskiej, z czasem - jak dowodzi Danuta Zawadzka w monografii Lelewel i Mickiewicz. Paralela - podchodzący do tematu Północy z rosnącą rezerwą ${ }^{18}$.

15 Tamże, s. 604-610. Zob. także, D. Zawadzka, Lelewel i Mickiewicz. Paralela, Białystok 2013, s. 276. O inspiracji Krasińskiego literaturą niemiecką pisała również Ewa Szczeglacka w książce Romantyczny Homo Legens. Zygmunt Krasiński jako czytelnik poetów polskich, Warszawa 2003, s. $48-55$.

16 Z. Krasiński, Listy do Henryka Reeve, s. 608-609.

17 M. Mochnacki, O duchu i źódłach poezji w Polszcze, w: tegoż, Pisma krytyczne i polityczne, t. 1., Kraków 1996, s. 95-96.

18 D. Zawadzka, Lelewel i Mickiewicz. Paralela, s. 239-244. 
W dobie rozwoju literatury romantycznej na gruncie polskim obiektem krytyki Lelewela stał się głoszony przez Mochnackiego pogląd o ścisłych związkach między literaturą Polską a kulturą Skandynawii. O przeciwstawnym, wobec romantycznego, rozumieniu Północy świadczy rozprawa Lelewela Powstanie, rozwijanie się i zgaśnienie bałwochwalstwa dawnych Skandynawów dołączona do drugiego wydania Eddy (1828). Zdaniem badacza kultura pierwotnej - jakby chcieli romantycy - Północy [Skandynawii - dop. K.A.] została skolonizowana przez średniowieczną kulturę Zachodu Europy. Jak pisze Danuta Zawadzka:

Średniowieczna romantyczność - zapewne przez związek z chrześcijaństwem i rycerstwem, a więc feudalizmem - symbolizuje dla Lelewela ponadnarodową kulturę o ekspansywnej naturze i niewyraźnej tożsamości. Jest to jeden z prądów zachodniej cywilizacji, która po przedostaniu się na wyspę [Islandię - dop. K.A.], zniosła niejako poetycką i religijną odrębność Islandii ${ }^{19}$.

Krytyczne rozumowanie Lelewela, wskazującego na „zgaśnienie” kultury dawnych Skandynawów, nie mogło spotkać się z entuzjazmem Krasińskiego, który postrzegał Północ zgodnie z duchem własnej epoki.

W świetle przytoczonej epistolografii poety wciąż może dziwić sąd Hieronima Chojnackiego, który w swojej pracy poświęconej Irydionowi opisuje różnorodne aspekty „północnej” strony dojrzałego dzieła Krasińskiego, nie bierze jednak pod uwagę fascynacji poety romantyczną Północą, która towarzyszyła mu już od młodzieńczych lat. Początkowy sąd badacza wydaje się jednak uzasadniony w świetle postawy Krasińskiego wobec innej „nieromantycznej" Północy, którą w wyobraźni poety stała się Rosja.

Utożsamienie Rosji z Północą stało się znamienne dla młodzieńczych utworów Krasińskiego: Polsce, Adamie Szaleńcu i o wiele bardziej dojrzałym już Agaj-Hanie. Podobne postrzeganie jednego z państw zaborczych Krasiński mógł zaczerpnąć z prac Lelewela, który o „północnym” rodowodzie imperium carów pisał w swoim Porównaniu Karamzina z Naruszewiczem (1822) ${ }^{20}$. Choć Krasiński nad wyraz sceptycznie odnosił się do stanowiska Lelewela wobec skolonizowania historycznej Północy Europy przez kulturę Zachodu, zdawał się znajdować o wiele więcej aprobaty dla postrzegania Rosji jako

\footnotetext{
19 Tamże, s. 276.
}

20 Porównanie było w Polsce przedlistopadowej znanym tekstem, ponieważ powstało - i zostało ogłoszone po rosyjsku - jako krytyczna recenzja monumentalnego dzieła Nikołaja Karamzina, nadwornego historyka carów, Historia państwa rosyjskiego, potem zaś ukazało się w polskiej prasie (1826) jako manifest romantycznej historiografii (zob. [J. Lelewel] Kultura Waregów i Stowian..., „Biblioteka Polska” 1826, t. 2). Lelewel mógł zatem uchodzić w czasach Krasińskiego za dziejopisarza, który przeniknął tajemnicę Rosji i podjął dialog z jej apologetami. 
północnego, podbitego niegdyś przez nordyckich Waregów imperium, niewolącego ojczyznę poety. Dowodem na podobne myślenie o Rosji są dzieła literackie Krasińskiego, w których powraca obraz Rosji - posępnego i złowrogiego terytorium skutego wiecznym lodem.

Północ w refleksji Krasińskiego przybierała więc dwie, skrajnie odmienne postaci: $\mathrm{z}$ jednej strony była utożsamiana $\mathrm{z}$ wyrastającym $\mathrm{z}$ niemieckiego romantyzmu obrazem wzniosłej utopii natury nieskażonej przywarami Zachodu (do której Krasiński jak wiadomo zaliczał również Polskę), z drugiej - z wareską Rosją, która w utworach literackich poety urasta do rangi przestrzeni demonicznej. Dla Agaj-Hana ważny będzie (w moim przekonaniu) nie tylko porządek estetyczny, naznaczony - jak pokazują dotychczasowi interpretatorzy - eksperymentami stylowymi i odnalezieniem własnego oblicza Północy, ale i dwie owej Północy genealogie: niemiecka oraz Lelewelowską. Ta ostatnia, $\mathrm{w}$ połączeniu $\mathrm{z}$ doświadczeniami biograficznymi z okresu powstania listopadowego, dostarczy frenezji ideowego uzasadnienia, związanego z tajemnicą Rosji, a z czasem Historii w ogóle.

\section{Romantyczna dystopia Północy}

Z perspektywy omawianej tematyki Agaj-Han przedstawia się jako dzieło wyraźnie związane z młodzieńczą Polska czy z genewskim Adamem Szaleńcem, utworami, w których odnajdujemy motyw Rosji jako demonicznego imperium Północy. W odróżnieniu od wspomnianych dzieł, wizerunek Północy w Agaj-Hanie został - jak sądzę - w dużej mierze zdeterminowany nie tylko przez wcześniejszą refleksję poety nad negatywnymi aspektami Północy rosyjskiej, ale również przez (nie)doświadczenie powstania listopadowego, które w znacznej mierze ukształtowało wyobraźnię poetycką Krasińskiego. Trauma powstania przeżywana $\mathrm{w}$ samotności, $\mathrm{z}$ dala od ojczyzny zaowocowała powstaniem szczególnej dystopii historycznej, za jaką w moim przekonaniu można uznać Agaj-Hana. Jak pisze Andrzej Juszczyk:

dystopia nie jest zwykłym przeciwieństwem utopii, ale raczej jej uzupełnieniem, jakie dokonuje się za pomocą doświadczenia i historycznej wiedzy autorów. Dystopia $\mathrm{w}$ praktyce pokazuje, na czym polegał błąd utopii, choć z nią nie polemizuje. Podczas gdy utopia zabierała nas w przyszłość, by pokazać teraźniejszość, to dystopia wskazuje nam mroczne aspekty aktualnej rzeczywistości, aby ostrzec przed ich konsekwencjami w przyszłości ${ }^{21}$.

21 A. Juszczyk, Stary wspaniały świat. O utopiach pozytywnych i negatywnych, Kraków 2014, s. 91. 
Eskapistyczny charakter powieści w połączeniu z oryginalną wyobraźnią poety zaowocował niezwykłą kreacją świata znajdującego się w przededniu historycznej apokalipsy, który w słowniku Krasińskiego zyska z czasem zaprzeczone miano sfery „nie-boskiej”. Centralnym elementem powieściowej rzeczywistości poeta uczynił skutą lodem, posępną przestrzeń Północy, na tle której rozgrywają się awanturnicze losy Maryny Mniszchówny, Zaruckiego i tytułowego Agaj-Hana. Plastyczny opis przestrzeni Północy pojawia się już na początku powieści:

Wieże Kaługi z dala pod chmur zimowych nawałą coraz szarzeją, bo wieczór się zbliża. - Ale dosyć dnia jeszcze, by oświecić te wzgórki, śniegiem obciążone, które kołem okrążają równinę, z której śnieg zmieciony; a nie wietrzysko go zmiotło, ale ręka ludzi, by na gładkiej ziemi panu lepiej przy uczcie i winie się działo; naokoło gasnące ogniska ${ }^{22}$.

Uwagę zwraca "filmowy” sposób obrazowania charakterystyczny dla prozatorskich ustępów z najwybitniejszych dramatów Krasińskiego. Na początku swojej opowieści poeta prezentuje bardzo ogólne "ujęcie” opisywanej okolicy. Dostrzegamy odległe wieże miasta Kaługa na tle zachmurzonego nieba. Nad okolicą zapada wczesny, zimowy zmierzch. Tym samym opisywana przestrzeń zdaje się uwalniać spod panowania sfery dziennej, zstępuje $\mathrm{w}$ domenę nocy, przez romantyków utożsamionej z obszarem przynależnym siłom diabelskim. Użyty przez Krasińskiego motyw, charakterystyczny dla tzw. "poezji nocnej” znacznie różni się jednak od analogicznego obrazu zmierzchu opisywanego w jednym z najwybitniejszych dzieł polskiego "czarnego romantyzmu” - Zamku kaniowskim ${ }^{23}$. W powieści poetyckiej Goszczyńskiego siły nocne w myśl ludowych wierzeń przybierają postać demonicznych puszczyków obserwujących tytułowy zamek. W opisach scen grozy jakich niemało można znaleźć na kartach Agaj-Hana - Krasiński rezygnuje z użycia motywów fantastycznych, ich miejsce zajmują drobiazgowe opisy makabrycznie okaleczonych zwłok i pola niedawnej bitwy.

W miarę narracyjnego „zbliżenia" do opisywanej przestrzeni, czytelnik dostrzega pierwsze, niecodzienne elementy krajobrazu, takie jak: kufle, dzbany, stoły, poszarpane płótna namiotów - rekwizyty niedawnej uczty wydanej przez samozwańczego cara - porzucony oręż i krzepnąca na śniegu plama krwi. Ślady niedawnej walki prowadzą „poetycką kamerę” Krasiń-

22 Z. Krasiński, Agaj-Han, Białystok 1998, s. 51. Dalsze cytaty pochodzą z niniejszego wydania i są oznaczane w tekście głównym skrótem A-H.

23 Zob. H. Krukowska, Czarny romantyzm Goszczyńskiego, w: S. Goszczyński, Zamek kaniowski, Białystok 1994. 
skiego w samo centrum niedawnej rzezi, w stronę zmasakrowanych ciał trzech pacholąt:

Wśród tego zgiełku leżą ciała trzech pacholąt; każdy padł inaczej, inaczej też leży - pierwszy z rozpłataną głową, z rozciągniętymi nogi, drugi z przeszytą piersią klęczy, jedną ręką przymarzł do ziemi, a plecy przymarzły mu do sani z tyłu; trzeci opiera się całym bokiem na grudzie, łokieć wparł w grudę, a czoło zwiesił na piersi. Na ich twarzach świeżość i młodość zestarzała się od bólu i od mrozu [A-H, s. 52].

Przestrzeń Północy rozciąga swoje panowanie nie tylko nad opisywanym planem, ale również nad ciałami poległych w walce bohaterów. We fragmencie poprzedzającym scenę pobojowiska uderza obraz zastygania - czy raczej„zamarzania” opisywanej okolicy. Szczegółowo pisał o tym Tomasz Łuczkowski, zdaniem badacza, opisywana „zamrożona” przestrzeń ma symbolizować zamieranie świata po dokonanej „eksplozji sił frenetycznych” ${ }^{24}$. Szczególną uwagę zwraca tu również zupełnie inny element opisywanego pejzażu, jakim jest swoiste przemieszanie obrazów będących pokłosiem działań człowieka i niezależnej od jego wpływu natury.

W odróżnieniu od twórców preromantycznych - z którymi chciałby kojarzyć młodego Krasińskiego Kleiner ${ }^{25}$ - natura opisywana w Agaj-Hanie zostaje obdarzona nie tyle prawem do życia, co szczególną samoświado mością, Nieszczęśliwa uczta wydana przez fałszywego Dymitra odbywa się w samym centrum równiny odciętej od reszty świata przez otaczające ją, pokryte śniegiem pagórki. Opisywana przestrzeń nosi wyraźne ślady działalności człowieka: pokrywający równinę śnieg zostaje zmieciony przez służących cara, dla przezwyciężenia panującego nad okolicą mrozu zostają rozpalone ogniska. Dalszy fragment utworu, w którym przedstawiony zostaje obraz po rzezi dokonanej na Dymitrze i jego ludziach, zdaje się sugerować, iż wydanie uczty w samym sercu dzikiej, odciętej od świata przestrzeni jest rodzajem gwałtu zadanego naturze.

Bezczeszcząca zdaje się być już sama obecność fałszywego cara, który w dalszej części utworu wspominany jest jako osoba jednoznacznie negatywna, co wyraźnie uwidocznia się w słowach Agaj-Hana naigrywającego się z bezgłowego trupa Dymitra II. Tytułowy bohater nazywa zabitego cara: rozpustnikiem, szalbierzem opitym winem i miodem, obmierzłą duszą

24 T. Łuczkowski, Pejzaż Pótnocy w "Agaj-Hanie” Krasińskiego (Pótnoc - od wzniostości do konwulsji), s. 168.

25 J. Kleiner, Pseudoromantyka "Agaj-Hana", s. 120. 
[A-H, s. 53-54]. Zbigniew Suszczyński określa przestrzeń Agaj-Hana mianem „mściwej materii” ${ }^{26}$. Termin ten w doskonały sposób ilustruje przyjęty przez Krasińskiego model kreacji przestrzeni, która poprzez swoje oddziaływanie zdaje się faktycznie mścić na ludziach dążących do jej ujarzmienia. Północna przestrzeń opisywana na początku utworu rozciąga swoje panowanie zarówno na przejawy aktywności i wytwory człowieka (dogasające ogniska, chaotycznie porzucone przedmioty), jak i samych ludzi. Szczególnie wyraźnie uwidacznia się to w opisie zmasakrowanych zwłok trzech pacholąt broniących samozwańczego cara. Północna natura niejako „pastwi się ” nad ciałami poległych: jeden z okrutnie zamordowanych bohaterów „przymarzł plecami do sań", kolejny "opiera się całym bokiem na grudzie”. Mimo iż każda ze wspomnianych postaci umiera $\mathrm{z}$ rąk ludzkich, to Północ dokonuje finalnego unicestwienia wszelkich śladów bytu człowieka. Obraz Północy unicestwiającej, jaki Krasiński kreśli na początku swojego utworu, podobnie jak i opisywany wcześniej obraz zmierzchu, stanowią rodzaj wprowadzenia czytelnika we frenetyczny, dystopijny świat powieści będący jednoczesną zapowiedzią zagłady bohaterów. Wracając do wspomnianego wcześniej porównania "czarnoromantycznych" światów kreowanych przez Krasińskiego i Goszczyńskiego, można stwierdzić, że Krasiński wyjaławia swój świat z romantycznej fantastyki i konwencjonalnej grozy na rzecz „mściwej” natury, która pełni w powieści rolę analogiczną do sił piekielnych ${ }^{27}$.

W dalszej części utworu ta żyjąca własnym życiem, północna natura zostanie w pewien sposób wygaszona - jednak nie wykluczona z opisywanego świata - aby pod koniec fabuły eksplodować po raz kolejny frenetyczną energią, która uwidoczni się w scenie unicestwienia Maryny i Agaj-Hana pod lodami rzeki Jaik.

Analogiczny obraz Północy pojawi się w powieści raz jeszcze (wyłączając wspomniane zakończenie) w rozdziale szóstym stanowiącym rodzaj przerywnika wątku Maryny i Zaruckiego. Krasiński opisuje tam wielonarodowe armie ścierające się na zgliszczach Cesarstwa Rosyjskiego. W odróżnieniu od kreacji zastygłej przestrzeni z początku utworu, w omawianym rozdziale przedstawiony zostaje obraz świata pogrążonego w ciągłym chaosie i frenetycznym pędzie. Bohaterowie Krasińskiego przywodzą na myśl żądne krwi wampiry niemogące zaspokoić nienasyconego głodu wojny, krwi i łupów:

26 Z. Suszczyński, „Agaj-Han” jako romantyczna powieść historyczna, s 37.

27 O kwestii „samoświadomości” natury pisała obszernie Maria Janion w jednym z colloquiów gdańskich, por. M. Janion, Natura, w: tejże, Romantyzm, rewolucja, marksizm: colloquia gdańskie, Gdańsk 1972, s. 245-296. 
Wielkie państwo moskiewskie pali się wciąż i dymi pożogami Polaków. Rozbiegli się husarze i potrząsając skrzydły jako drapieżne orły, ulatują ponad gruzami i gęstym trupem. Wycieczki „straceńców” nie wstrzymane u Kaukazu, w głębie azjatyckie się zapuściły. Każdy rabunkami pnie się do bogactw, rycerskim czynem do chwały; miasto zburzyć, wieś spalić jest ich chlebem powszednim. Z niewolnicami pląsają nad stósami popiołów, grzeją się pośród mrozu na zgliszczach pałaców, winem i miodem sączą się wąsy - tym lepiej im potem usta kleić z ustami Azjanek [A-H, s. 93-94].

Wraz z ginącymi jednostkami zdaje się umierać cały świat powołany do życia przez człowieka. Fakt ten uwidocznia się w przyjętym przez Krasińskiego opisie ruin miast, cerkwi, pałaców, na których to gruzach toczą walki rycerze $\mathrm{z}$ najodleglejszych zakątków. W opisie wojowników - przyrównanych do barbarzyńskich zdobywców Rzymu - uderza przede wszystkim różnorodność ich strojów, języków i obyczajów; Maciej Szargot zestawia bohaterów z biblijnym stujęzycznym smokiem ${ }^{28}$. Barwność i różnorodność opisywanych postaci sprawiają, iż czytelnik ma wrażenie jeszcze większego chaosu panującego w opisywanym świecie. Zagłada bohaterów w dużej mierze zostaje zdeterminowana przez działanie morderczej, mroźnej Północy. Ofiarami rosyjskiej zimy padają przede wszystkim przybysze z dalekiego Południa:

Ciągnącym z cieplic nieraz zima zajrzy w oczy; z szalów przewieszonych na plecach, $\mathrm{z}$ winogron $\mathrm{u}$ siodła wiszących, z kamieni Wschodu szydzi sobie mścicielka Północy; mróz im członki ćwiartuje i powieki spuszcza nad oczyma. Tak wśród wozów i koni całe padają hufce, a Moskwicin, który jeszcze wczoraj o południu lękał się ich wąsów, kiedy przejeżdżali obok chaty, dziś śmiało, klaszcząc w ręce, depta po nich i błogosławi niebu [A-H, s. 94].

Przybywający z Południa rycerze wkraczają w przestrzeń, która jest im obca, a mordercza Północ - jakby naigrywając się z nieświadomych jej zgubnego działania przybyszy - po raz kolejny dokonuje ironicznej zemsty. Ironicznej, bo rycerze będący przed chwilą postrachem „Moskwicinów” zostają zgładzeni przez rosyjską zimę. Wyraźnie apokaliptyczne obrazy powoływane do życia przez Krasińskiego stanowią rodzaj symbolicznego zmierzchu nie tyle fizycznego, co historycznego świata. Po dokonanej zagładzie „bohatyrów" miejsce niedawnych walk staje się głuche i wymarłe: "Głucho, samotno - chyba, że słychać pluskanie krwi z żył trupów” [A-H, s. 98]. Cytowany fragment sprawia wrażenie kalki słynnego zdania z Marii Antoniego Mal-

28 M. Szargot, Kosmos Krasińskiego, s. 68. 
czewskiego: „I pusto - smutno - tęskno w bujnej Ukrainie” 29. Oba utwory zdaje się łączyć również niezwykle pesymistyczna, egzystencjalna filozofia, w Marii zamykająca się w słynnym fragmencie „Pieśni Masek”: „Bo na tym świecie Śmierć wszystko zmiecie; Robak się lęgnie i w bujnym kwiecie" $^{\prime 30}$. W podobnie sentencjonalnym tonie w Agaj-Hanie wypowiada się pokonany Zarucki: „Życie jest marną bitwą, w której człek nigdy z konia nie zsiada i walcząc bez ustanku, wreszcie przegrać musi". W jednej ze swoich prac Zbigniew Sudolski dowodzi, że Krasiński poznał Marię stosunkowo późno ${ }^{31}$, mimo to, podobieństwa między genewską powieścią Krasińskiego a poematem Malczewskiego po raz kolejny świadczą o pokrewieństwie wyobraźni autora Nie-Boskiej Komedii oraz jednego z najwybitniejszych przedstawicieli polskiej „szkoły ukraińskiej” ${ }^{32}$. W odróżnieniu od Północy obecnej w Marii, a więc uwidoczniającej się w melancholijnych, osjanicznych krajobrazach opustoszałej Ukrainy, przestrzeń Agaj-Hana ulega tylko chwilowemu wyciszeniu, aby po chwili letargu ujawnić swoją destrukcyjną obecność.

Krajobraz Północy stanowi dominujący element opisywanej rzeczywistości również w chwili, gdy dobiega końca mordercza, rosyjska zima. Jednak wiosna - która nadchodzi w chwili ucieczki Maryny z więzienia - zdaje się być posępną karykaturą prawdziwego obrazu wspomnianej pory roku: „Zaduch wilgoci i zgnilizny wokoło [...] odrywają się od ścian wyziewy i ciągną nad głowami przechodzących jak fałdy całunu. One są zwiastunkami wiosny w tych lochach" [A-H, s. 84]. Północna natura nie odstępuje bohaterów również w chwili szaleńczej ucieczki przy świetle wiosennego księżyca:

Lecą pod sklepieniem z liści, między którymi tu i owdzie czołga się promień księżyca - a wiatr szumi głosem tysiąca gałęzi niezrozumiale, choć co chwila zda się, iż z tego zamętu pewniejsze wydobędą się tony, na które czeka przez długie godziny młodzieniec zakochany lub pielgrzym dumający o Bogu - na które i chwili nie czekał Sahajdaczny, bo zrozumiał natychmiast tę mowę.

29 A. Malczewski, Maria. Powieść ukraińska, Białystok 2002, s. 182. O powiązaniach Agaj-Hana z Maria pisał również Tomasz Łuczkowski we wspominanym wcześniej artykule Pejzaż Pótnocy w "Agaj-Hanie" Krasińskiego (Od wzniostości do konwulsji), s. 183.

30 Tamże, s. 157.

31 Z. Sudolski, „Maria” w lekturze i refleksji Zygmunta Krasińskiego, w: Antoniemu Malczewskiemu w 170 rocznice pierwszej edycji „Marii", red. H. Krukowska, Białystok 1997, s. 420-430.

32 O podobieństwie między Agaj-Hanem a twórczością przedstawicieli „szkoły ukraińskiej” pisała także Maria Janion. Badaczka zwróciła przede wszystkim uwagę na zbieżności stylistyczne między powieścią Krasińskiego a Zamkiem kaniowskim czy Maria, zaliczając tym samym Agaj-Hana w poczet najwybitniejszych dokonań polskiej powieści romantycznej (M. Janion, "Agaj-Han" jako romantyczna powieść historyczna, s. 49-79). 
- To wiatr z północy tak hasa, miłościwa pani - on na jutro napędzi chmury, więc gońmy co żywo do spławu i czajek, by pogodną jeszcze nocą odbyć żeglugę! [A-H, s. 88]

W wypowiedzi narratora nieoczekiwanie pojawia się bardzo wyraźna aluzja do Północy w jej romantycznym rozumieniu, a więc Północy, którą Krasiński bardzo dobrze poznał i zaaprobował jeszcze przed wybuchem powstania. Mogłoby się wydawać, że wspomniana przez narratora romantyczna, transcendentna Północ, w stronę której zwracają się zakochani bądź poszukujący Boga ludzie, będzie stanowiła przeciwwagę dla mrocznej kreacji Północy rosyjskiej. Na uwagę zasługuje jednak fakt, iż uwidocznia się to przede wszystkim $\mathrm{w}$ zakończeniu powieści, gdzie ujawniający się narrator nazywa tytułowego bohatera powieści „dziecięciem swej wyobraźni”. Utopijna, romantyczna Północ - wspomniana przez narratora jakby mimochodem - zostaje niemal natychmiast skonfrontowana $\mathrm{z}$ wypowiedzią Zaruckiego o „wietrze z północy”. Podobnie jak romantyczny narrator, bohater dostrzega w Północy siłę sprawczą, która w jego refleksji przybiera jednak postać "czarnych chmur", a więc konkretnego zagrożenia.

Nie-boskość rzeczywistości powołanej do życia przez wyobraźnię Krasińskiego $\mathrm{w}$ pełni uwidocznia się $\mathrm{w}$ ostatnich rozdziałach powieści, gdzie opisane są lodowe pustkowia za rzeką Jaik [dziś Ural - przyp. K. A.]: „Za Jaikiem ciągną się błonia, przeklęte od Boga; wicher jedynym jest ich panem - on tylu niewolników ma na swoje rozkazy, ile ziarn piasku drzemie w pustyni, przeciągłymi świsty budzie je i ożywia, potem, jak mu się spodoba, posyła na wsze strony świata" [A-H, s. 121]. Dalej narrator przywołuje obraz pustyni zimową porą:

Śnieg obsypał piaski, rzeka stanęła, szron wszędzie połyska; kilka dni sokołowi lecieć ponad tymi stepami, a wzroku mu nie stanie, zatrzepocze skrzydłami, raz jeszcze się podrzuci i padnie olśniony na biały śnieg śród gwiazdeczek z lodu. Tam, gdzie pustynia, zda się, przylgnęła do nieba, podnoszą się wzgórza, dalej podnoszą się skały - bez drzew, nagie, chude, jakby szkielety olbrzymów, których ród wyginął, a skamieniały kości. Tu dopiero zaczynają się manowce i bezdroża, czernieją paszcze jaskiń, w których snuje się para zjadliwa, granitowe słupy się ciągną, a między nimi kopce ze śniegu; lody, jako blachy przykuły się do grzbietów skał [...] [A-H, s. 121].

Sroga, nieprzyjazna człowiekowi przestrzeń staje się chwilowym schronieniem dla Maryny i Zaruckiego - niedawnych zdobywców Astrachanu uciekających przed wysłannikami cara widzącego w Mniszchównie i jej towarzyszu (słusznie zresztą) zagrożenie dla jego panowania nad Moskwą. Śladami ukrywających się bohaterów podąża także oszalały z miłości do 
Maryny Agaj-Han kryjący się pod imieniem Nuradyna Murzy. Wspierani przez zdziesiątkowane oddziały Zaruckiego, bohaterowie kryją się w jednej z górskich jaskiń. Wkrótce z głodu i wycieńczenia umiera dwuletni syn Maryny ${ }^{33}$. Oczekujący na rychłą śmierć Zarucki wzywa duchy towarzyszących mu przed laty poległych wojowników, aby dodały mu otuchy przed zbliżającą się ostatnią w jego życiu walką. Na wezwanie bohatera nieoczekiwanie przybywa jeden z jego "mołodźców” wzięty początkowo za przywoływanego ducha. Żołnierz donosi swojemu dowódcy o zbliżających się oddziałach nieprzyjaciela, po czym umiera, wykrzykując imię Sahajdacznego. Autor daje do zrozumienia, że oto bohaterowie znaleźli się w centrum nie-boskiego, Północnego świata wyzutego spod wpływu wszelakiej metafizyki. Wzywany przez Zaruckiego świat duchów milczy, bowiem bohaterowie wkroczyli w sferę, która jest dla owego świata niedostępna. Po raz kolejny Krasiński tworzy wyraźną opozycję między powieściowym światem Północy rosyjskiej a jej romantycznym, utopijnym wizerunkiem. Doświadczanie Pó1nocnej natury w oczach romantyków stanowiło rodzaj obcowania z rzeczywistością o wymiarze transcendentnym. Północny ",anty-raj” Agaj-Hana zostaje tej sfery pozbawiony.

Przyjęta przez Krasińskiego kreacja północnego świata znajduje dopełnienie $w$ finalnej zagładzie Maryny i jej prześladowcy. Ogarnięty szaleństwem Agaj-Han topi swoją ukochaną w mroźnych wodach Jaiku, sam zaś odpływa ku morzu na topniejącej lodowej krze. Interesujące jest to, co dzieje się z otaczającą bohaterów przestrzenią na chwilę przed ich okrutną śmiercią:

Oba brzegi cienie swe na Jaik rzucają, pośrodku nich, gdzie już zetknąć się mają, wstęgę krwawego światła rozciągnęły zachodzące promienie; do tej kiedy doszedł Agaj-Han, stanął i szukał czegoś wokoło - ale nie złożył Maryny. Choć dyszał i kroplami potu oblane miał czoło. Czego szukał, znać, że dojrzał, bo skoczył i znowu w bieg się wprawił, i leciał w stronę morza [...] [A-H, s. 149].

Krasiński nadał ostatnim scenom swojego utworu wyraźnie apokaliptyczny wymiar. Świat Agaj-Hana pęka i kruszy się wraz z pokrywającym rzekę lodem, po którym pędzi oszalały z miłości Agaj-Han wiodąc Marynę ku nieuchronnej zagładzie. Nieokreślona, tajemnicza siła zdaje się wskazywać bohaterowi miejsce, w którym powinna zginąć Maryna. Agaj-Han odnajduje wreszcie wirujące „źródło odwieczne”, w którym swoje życie kończy bohaterka.

33 Według relacji Niemcewicza został on uduszony przez wysłanników cara. Por. Z. Krasiński, Agaj-Han. Powieść historyczna, s. 50. 
Scena śmierci Maryny prowokuje do przypomnienia obrazu zamarzniętych ciał obrońców Dymitra dotkniętych destruktywnym działaniem północnej natury. „Północna” śmierć Maryny pozbawiona jest frenetycznej makabry tak charakterystycznej przecież dla scen mordów przewijających się co chwilę na kartach powieści. Wspomina o tym również Agaj-Han przekonany o okrutnej śmierci czekającej Marynę z rąk wysłanników cara: „cała, nieskażona, jako piękna jest na ziemi, tak piękna zstąpi w dół - a w głębi miękki piasek - i rozciągnie się na nim jako na łożu rozkoszy" [A-H, s. 148]. Miejsce, w którym ma zginąć Maryna - określone mianem "źródła odwiecznego" jest elementem rzeczywistości pradawnej, nietkniętej przez człowieka. W analogiczny sposób przedstawia się cała rozciągająca się przed bohaterami przestrzeń krańca znanego im świata.

Płynącemu ku otwartemu morzu Agaj-Hanowi wydaje się, że pochłania go lodowy krajobraz, jednocześnie bohater traci świadomość samego siebie: „woda i lód - oto świat jego - ale on tego nie poznaje świata, bo dziwne otaczają go kształty, bo płynie jak strzała i te kształty płyną z nim [...]" [A-H, s. 152]. Otaczająca bohatera przestrzeń przywodzi na myśl krajobrazy z płócien Friedricha, na których człowiek przedstawiony jest w chwili konfrontacji z rozciągającą się przed nim nieskończoną, spowitą mgłą przestrzenią. W zakończeniu Agaj-Hana powraca ledwie zarysowany wcześniej problem skonfrontowania Północy w jej romantycznym rozumieniu - a więc Północy transcendentnej - z jej dystopijnym wizerunkiem powołanym do życia przez wyobraźnię Krasińskiego. Poeta nie daje odpowiedzi na pytanie, czy Agaj-Han zmierza ku uosabiającej Boga nieskończoności, czy - parafrazując słowa bohatera Straży nocnych Augusta Klingemana - „ku wielkiemu Nic”.

Wspomniana wcześniej dystopijność Agaj-Hana nabiera pełnego znaczenia w świetle dwoistości poglądów poety na temat Północy. Kreując "nie-boski", pozbawiony wpływu transcendencji świat Agaj-Hana, Krasiński dokonuje znamiennego odwrócenia utopijnego wizerunku Północy dominującego w pierwszej fazie polskiego romantyzmu i zaaprobowanego przez poetę. Owo „odwrócenie" romantycznej Północy uwidocznia się przede wszystkim $\mathrm{w}$ tych fragmentach powieści, gdzie przedstawione zostaje niszczące działanie północnej natury, która w romantycznym (utopijnym) rozumieniu miała ratować człowieka przed zgubnym wpływem cywilizacji. Powołanie do życia "dystopijnego" świata Północy, który ma swoje korzenie w myśleniu poety o Rosji, zdaje się wynikać w dużej mierze z doświadczenia powstańczej traumy. Agaj-Han odczytany w podobny sposób prezentuje się jako dzieło będące zarówno wcieleniem wyobraźni poety dotkniętej przez traumę powstania, jak również utworem, w którym dochodzi do ideowej i estetycznej kontaminacji rozmaitych wariantów Północy. 


\section{Shades of the North in Zygmunt Krasiński's Agaj-Han Summary}

The author of the article analyses Zygmunt Krasiński's views concerning romantic idea of the North. Additionally, he examines the poet's polemics with Joachim Lelewel. The final conclusion demonstartes that Krasinski developed his own vision of the North, and that it contradicts the generally accepted utopian image which dominated the early stage of Polish romanticism.

Keywords: Polish romanticism, vision of the North, Zygmunt Krasinski, Agaj-Han, Joachim Lelewel 